\title{
Attitudes of Stakeholders Towards Physical Punishment on Pupils of International and National Schools in Kampala District, Uganda
}

\author{
Mbikyo Mulinga Damien \\ Faculty of Education, Kigali Institute of Education \\ P.O. Box 5039, Kigali, Rwanda \\ E-mail:mbikyomulda@hotmail.com \& dmmulinga@educ.mak.ac.ug
}

Received: February 15, 2011

Accepted: March 11, $2011 \quad$ Published: February 1, 2012

doi:10.5430/wje.v2n1p96

URL: http://dx.doi.org/10.5430/wje.v2n1p96

\section{Introduction}

A punishment is an action that makes somebody suffer because of breaking the law or doing something wrong. It is a penalty for misbehavior with the intention of shaming a child in order to make him/her a counter productive. It is a deliberated infliction of pain intended to correct or punish. In schools, physical punishment is used as a corrective measure in order to guide the child. The cane was the common tool used for correcting the child. This cane was called light cane or junior cane which was always present in class in Asia, Europe and the European colonies in the $19^{\text {th }}$ and $20^{\text {th }}$ centuries, to be administered to young school children.

However, views towards physical punishment are divergent depending on institutional philosophy, the level of civilization and the cultural backgrounds. Psychologists think that all forms of punishment such as caning inclusive have different outcome; children would be counseled and helped to overcome the unwanted behavior rather than resorting to the cane. Humanism for example, implies both a human and a humane approach to educational problems. According to this philosophy, the nature of the child and its growing mind should not be suppressed by cruel school punishment and rigid methods of institution (Nicholas Hans, 1982). Human rights activists in their turn, insist that corporal punishment is a torture. As human rights defenders, they see in physical punishment a domestic or family violence and child abuse. United Nations' Declarations and Conventions advocate for child protection since 1949 and prohibit universally the use of physical punishment as it is noted by the UNESCO (2001). Some decades ago, Western educationists believed that the use of physical punishment in homes and schools was a barbaric relic of a bygone age which is incompatible with the present day of the humanitarian ethics; physical punishment is an archaic method for a country cherishing progress, they assert. They stress that physical punishment is a tit for tat action used by people with lower level of moral control and especially by weak teachers (Docking, 1998a). Those who support the Eurocentric view of physical punishment think that hurting a child is wrong and amounts to child abuse. They argue that parents and teachers should use a non-violent and positive corrective measure (Beth, 1994).

To the same extend, some assert that violence used as a means of discipline is illegal because, if one cannot smack his cat or dog which are animals, he/she then should not do it to the child who is a human being (Pimheiro, 2000). Here, teachers are advised and warned that if the need for punishment crops up, it must be carried out, otherwise authority is undermined and anarchy threatens; but corporal punishment is no longer acceptable and it would be foolish for the new teachers to use it (Thompson, 1973: 55-57). As Cohen and Manion, 1977: 183-184 can stress, prohibition of physical components such as caning, strapping, striking, or shaking have been taken as fearsome actions and teachers are warned that these actions should not be used in schools because these are coercive sanctions

On the other hand, supporters of physical punishment argue that the use of the rod brings out the best in the child; that without corporal punishment, the school would descend into chaos and children would become more unruly by the time they reach high school (Mararike (2005). Fournier (2004a), a French educationist who supports the use of physical punishment demonstrates that in education spanking should not be an isolated measure. The USA Criminal Code justifies force used against a minor when a parent, guardian or other responsible reasonably believes, for the general care and welfare of a minor, it is necessary to prevent or punish such a minor's misconduct.

The 2000 smacking paper published in the United Kingdom states that a new attempt is being made to clarify and improve the law on the punishment of the children in Scotland. The law states that parents should have the right to smack their children in disciplining them. This position is supported by the majority of people in Scotland. They want to 
amend the law protecting children from punishment that is harsh, degrading and inappropriate in a descent society. Even Eremu (2004a) has reported that in Britain, an alliance of lawyers, childcare professionals and politicians joined forces to condemn as unworkable, plans to jail parents who administer anything stronger than a light smack to their children. Controversies on the issue of physical punishment seem to be rooted in different cultural beliefs and the current circumstances coming up in our societies. Used for different purposes, this issue is in our time a challenging practice that leads stakeholders to blame each other. Despite stereotypes from these competitive groups, one cannot confirm having totally managed to successfully come to a corrective measure. No one has been identified having set up an example to follow. Everywhere, complaints against children' manners are discouraging, driving stakeholders to take various actions on children.

An education stakeholder is a person who has a share or interest in education matters. To the researcher, school administrators, parents, teachers and pupils themselves have great interest and share in education. An international school is a private school that gathers students from different countries and various cultures while a national school is a school established or aided by a national society for promoting education for the people (Babcock, 1993). In Uganda, a national school is a school aided by the government and the parents. Both the government and parents have financial obligation for the education of the child (White Paper, 1995).

This study was drown from the theory of social learning proposed by Bandura in 1973 which stipulates that children learn behaviors through trial and error conditioning and through vicarious learning. In addition, the theory stipulates that children also learn by observing the behaviors of others through positive and negative consequences those behaviours bring. Related to physical punishment, this means that as children try to learn through trials and errors, they make mistakes. Adults' reactions to these mistakes vary. Others punish physically, some emotionally.

Physical punishment is the use of force (no deadly force) to discipline the child in order to safeguard and promote his welfare. In this way, the punishment is used for the general care of the child. Therefore, it is necessary to prevent or punish the child's misconducts (Donnelly and Murray, 2005a). A disorder in a community is like a disease in a human body that needs a medical doctor who cures using a bitter medicine (sour drugs and injections) to heal the patient. Similarly, education stakeholders use physical punishment as one of strategies of guiding children to behave in a more acceptable manner. Children need order to fulfill conditions required to become productive, useful and happy community members. Sometimes, children do not easily see the danger facing them when they do wrong. The role of the parents, the school and other care givers is to help children to achieve the community's expectations.

However, physical punishment is not conceived the same way by all stakeholders. Some of them consider that children learn from the consequences of the wrong done while others think that children must be protected from physical punishment because it is a coercive measure rather a corrective one. In protecting children from physical punishment, some stakeholders believe that laws should be implemented in order to avoid abuses against children while others are against these laws. In every society, physical punishment concern has created two competitive groups that need to find compromise in correcting and guiding children.

On the other hand, reference to physical punishment is a result of cultural beliefs.

Supporters of physical punishment, especially Africans, argue that corporal punishment is culturally justified. In Africa, physical punishment is traditionally acceptable. Africans believe that the argument under which corporal punishment is an abuse of children's rights is a Eurocentric view that does not tally with African norms and values. In this respect Mararike (2005) declares that physical punishment is justified by the long tradition under the colonial rule in Africa. He states the colonial era during which Africans who refused to pay taxes or who did not obey the colonial rule were caned in public. Therefore, caning was a symbol of authority and being a colonial authority meant to cane an African lawbreaker (World punishment, 5/9/ 2005).

Nakawa (1998a) clarifies these thoughts when she states African writers who believe that corporal punishment is cheap and easy to administer; that it is always available, elicits quick response and requires little intelligence; that in its use, corporal punishment is straight forward and logically acceptable compared to other types of punishment.

Physical punishment is not only supported by Africans. It is also supported by Asians, Australians, Americans and Europeans. In Asia, physical punishment was related to educational purposes, training and other ways of living. Plato (427-347 BC) claimed that it is well and good if the child obeys; if not, he is straightened by threats and blows like a piece of wood. For Plato, appraising or punishing a child depended on obedience or disobedience. Similarly, Aristotle (384-322) observed that youths should not be instructed in amusement; instead of learning with amusement, learning must be accompanied with pain through which the child should be disgraced and beaten. For Aristotle, there is no learning without pain. 
There are other practices that were used in Asian societies as ways of physically punishing children. This is the case of the Spartans, Romans, Indians, and Hebrews. The Spartan society believed that beatings were to promote obedience and value and to harden the body and soul, all for the service of the State. Hebrews' statements on physical punishment are found in the Bible (in Proverbs) arguing that whoever spares the rod does not like his son, but whoever loves him discipline him carefully ( Proverbs 13:24); that folly is bound up in the heart of a child but the rod of discipline will drive it far from him (Proverbs 22:15), that a rod of correction imparts wisdom, but a child left to him disgraces his mother (Proverbs 29:15). In this ways, Hebrews believed that physical punishment led to corrections, discipline, and taught wisdom to the child. In Eastern Asia, paddling of children is still allowed. In China and Taiwan, corporal punishment is still widely practiced in schools. There, it is legal to punish one's own child using physical pain. People of this region believe that a minimum amount of corporal punishment against their own children is appropriate and necessary. Physically punishing a child shows that the child belongs to the parent. In ancient India, a wife, a son, a slave and a pupil who had committed faults was beaten with ropes or split bamboo on the back part of the body not on the noble parts. Physical punishment was the result of wrongdoings, especially to individuals with inferior social status. Australia's aborigines deliberately inflicted physical pain on the boy as a training and test of manhood. In certain tribes of North American Indians, beating was a common punishment; flagellation was considered as a cure for disease and a sexual stimulant. For these societies, physical punishment was intended for training, testing how one has become mature, healing somebody and stimulating one's sexual capability. Physical punishment was in use in Rome and schools were places of regular beatings with the scutia (a leather strap), the ferula (rod), the flagellum (a whip of number of knotted strands), or the virga (a birch-switch). In this society, whoever attended school was expected to be beaten (Wilson, 2001).

These various practices on physical punishment seem to be divergent but have common concern showing that in every society, children rely on their parents and other adult caregivers to help them learn about the World. Their role is to help children to be happy and productive members of the community. To achieve this, children need order in their every day life to fulfill conditions that are required to meet the community's expectations. Hence, discipline is seen as something which is done to ensure that children behave well. This would involve punishment that is considered by some stakeholders as a strategy of guiding children to behave in an acceptable manner.

In both traditional and modern societies and communities, punishments are regulated in accordance with customs rules, cultural laws and governmental codes. In Kenya, caning is the only form of corporal punishment permitted by the Kenyan Ministry of Education. Every class room teacher has the authority and independence to can a student. The Kenyan Law stipulates that an offender may be given at least six strokes by the teacher in the presence of the Head teacher. Boys are hit on the buttocks and the backside while girls are hit on the palm and the backside of the hand.

The problem in Kenya is that many teachers abuse the existing regulations and limitations in the use of corporal punishment by the Kenyan authorities; teachers do not follow them. Corporal punishment is unchecked, widespread, often brutally and arbitrary used. Children are strapped, pinched, hit, whipped, kicked or boxed by their teachers. This way of punishing has lead to massive school drop outs in Kenyan schools (Human Rights Watch, 1999).

Since the 1948 British Act of education reform, the United Kingdom as whole, follows a policy of "Loco Parentis" in which all teachers are to assume the role of the parents once a child is in the school territory. This act considers detention and exclusion as the fairy common punishments at school; corporal punishments are illegal and hereby are strictly prohibited to carry out (Wikipedia, retrieved on 11December, 2006).

In the USA, the Texas Penal Code allows the use of force, but not deadly force, against a child younger than 18 years. Use of force is justified if the actor is the child's parent or a step-parent or is acting in 'loco parentis' to the child (e.g. a teacher, a social assistant, etc). When and to the degree the actor reasonably believes that force is necessary to discipline the child to safeguard or promote welfare, he/she is justified by the Law. The USA Criminal Code justifies force used against a minor when and to the extend that a parent, guardian, or other responsible reasonably believes, for the general care and welfare of a minor, it is necessary to prevent or punish such a minor's misconduct. This force should however not be deadly (Donnelly and Murray, 2005b).

\section{Physical Punishment in Uganda Primary Schools}

This study was about attitudes of stakeholders towards physical punishment on pupils of international and national schools in Kampala District after 10-year period of abolition of the punishment by the Government of Uganda.

Daily observations show that in Uganda, education stakeholders in international and national schools seem to conceive and understand the use of physical punishment differently. Stakeholders from international schools criticize national schools believing that these are mistreating their pupils in beating them as if children were not human beings. The 
1995 Constitution and the subsequent enactment of the 1996 Children Act have all ensured that basic education is a legitimate and basic human right of all the children in the country (Leggett, 2001a). Terming on corrective measures, the National Curriculum Center (1999:308) has designed a chapter on children's rights. In this curriculum, children from Primary Three are taught and trained to resist abuses such as physical punishment from families and schools.

Under children Act, section 94(9)59, the Uganda Law (2000), stipulates that no child shall be subjected to corporal punishment. The Child Law Committee (1992:16) indicates that the child in Uganda should have the right to be protected from all forms of abuse and exploitation. At the higher national level, the Uganda Constitution (1995), article 24 states that no person shall be subjected to any form of torture, cruel, inhuman or degrading treatment because corporal punishment has element of violence and can be misapplied since there have been cases where parents and teachers mistreated children to the extend of killing. But the Human Rights Commission Tribunal based on the 1999 Uganda Supreme Court ruling against corporal punishment in penal system did not condemn all corporal punishments in schools.

Despite these national regulations, physical punishment is still in practice in correcting and disciplining children in Ugandan schools as it was reported by scholars and writers like Lennan (2004) who reports on complaints of children testifying that since they are born and grew-up they have been beaten and cannot escape beatings which are even followed by shouting, insults and hard control. He reveals that corporal punishment is part of two many children's normal lives in homes and schools in Uganda; that the most common form of beating in homes is with a belt while in schools; hat despite the ban, corporal punishment is most often with a ruler, stick or a board duster on the hands. The researcher writes that some pupils have testified having been caned 58 times at school.

Eremu (2004:37c) quotes a government leader who warned teachers who beat up pupils to check their habit. Pupils were asked to report to authorities teachers who beat or subject them to any form of brutality. The leader claimed that beating children must stop because children are brought to school to learn new ideas and skills, not to be traumatized by their teachers (The New Vision, September 20, 2004: 37).

The Ugandan Ministry of Education banned use of corporal punishment because there was absence of clear procedures and guidelines on the application and uncontrolled use of the punishment. Hence, it was necessary to put complete stop before a policy on the issue is finally implemented. This decision raised a lot of complaints from many parents and teachers who did not agree with the decision (Nagawa, 1998:3-5 b).

In a debate held by teachers from different schools in Uganda, teachers have claimed to be given alternatives to deal with the unruly students. Teachers find hard to surrender their old habits of corporal punishment. Some teachers do not know what to do because in any of the education curriculum there is no component of how to punish students. Since they do not know what the limits should be, teachers punish students using their own experience. Their experience has shown that corporal punishment is instant, quick and does not involve a lot of time. Some teachers have realized that at times, teachers are forced to cane because sending some wrong students out of class will affect some, but for others, the cane will work to get them on course.

Other teachers claim that there is no research done to show that corporal punishment makes a student better. Helping a student is about reinforcing the good and in turn, the teacher will be destroying the bad; therefore, motivation is the key of discipline; that a person who uses corporal punishment does not vary the methods of teaching; that a stubborn student needs love, counseling and guidance (Mugemuzi, 2003).

Having realized that teachers did not abide the warnings, in 2006, the Ministry of Education and Sports banned corporal punishment in colleges, primary, nursery schools and infant classes citing physical punishment as a torture causing injuries on students. The Ministry insisted that the use of the cane and any other form of punishment that would cause injury must stop with immediate effect, even the use of bare hands

The Ministry advised that instead, teachers should find other alternatives for disciplining children such as disciplinary book and other non-violent practices. The Ministry suggested that schools should review their respective rules and introduce more professional and acceptable sanctions to replace manual labor and caning; that schools should record any disciplinary action in the punishment book indicating the type of offence, the respective type of punishment authorization and the particulars of the person administering the punishment so that a regular system of records is maintained (Natukunda, 2006). These punishments used as corrective measures in homes and schools have raised a lot of controversies among parents, teachers, politicians, policy makers, pupils and other educationists in Uganda. Kampala District has 5 divisions in which the schools were selected during the research survey; these are Central/Kampala, Kawempe, Makindye, Nakawa and Rubaga Divisions.

<Table 1 about here> 
The purpose of this study was to assess attitudes of stakeholders towards physical punishment in schools in Kampala District. In this study stakeholders were requested to state their actions and feelings towards the use of physical punishment in schools. The objective of the study was to investigate attitudes of stakeholders towards physical punishment in schools, find out circumstances which commonly lead to physical punishment and to explore perceptions of stakeholders on alternative forms of punishment.

To achieve these objectives the researcher used survey methods in his research methodology. As shown in Table 2, the sample was composed of 360 respondents/subjects (school administrators, parents, teachers and pupils). These respondents were subjected to interviews and questionnaires. In these aspects the research was carried out under the requirements of both qualitative and quantitative research. Attitudes towards physical punishment as a dependent variable depended on the use of physical punishment as an independent variable. Therefore attitudes of stakeholders are influenced by physical punishment. To analyze the data the researcher coded similar issues and therefore calculated percentages in order to estimate the average of respondents who appreciate or do not appreciate any issue concerning the use of physical punishment in schools.

<Table 2 about here>

\section{Results of the Study}

In this chapter, the researcher, analyzed, interpreted and presented the results from the field. The researcher's concern was to assess the attitudes of stakeholders in international and national schools towards physical punishment.

In both international and national schools parents agreed that physical punishment has negative effects. In international schools, $80 \%$ of the parents disagreed that physical punishment is a good corrective measure but it has negative impacts. Similarly, $82 \%$ of the parents in national schools agreed that physical punishment has negative impacts although it is a good corrective measure. In the two categories of schools, majority of the parents disagreed that physical punishment keeps discipline. This was reported by $80 \%$ of the parents in international schools and by $69 \%$ ) in national schools. Only $20 \%$ of parents in international schools and $22 \%$ in national schools agreed that physical punishment keeps discipline in school. This means that majority of the parents in both international and national schools have negative attitude towards physical punishment and do not like the practice on their children, although $60 \%$ of the parents in national schools agreed that physical punishment is a good corrective measure.

However, majority of the parents disagreed that a teacher who beats children must be dismissed from school. This was reported by $68 \%$ of the parents in international schools and by $88 \%$ in national schools. This statement was supported by few parents, $28 \%$ in international schools and by $6 \%$ in national schools. This means that parents do not support dismissal of the teachers, even if they use physical punishment on their children.

Majority of the parents, $64 \%$ in international schools wanted abolition of physical punishment while in national schools many parents, 54\% did not want abolition of physical punishment. Disagreement on abolition of physical punishment was supported by $32 \%$ in international schools and $37 \%$ in national schools wanted abolition of physical punishment (these data may be found in Table 3). These results show that parents in the two categories of schools had different views on abolition of physical punishment on their children.

\section{$<$ Table 3 about here>}

Table 4 indicates responses of teachers who responded to similar questions. It shows that majority $(76 \%)$ of the teachers in international schools disagreed that physical punishment is a good corrective measure and majority, $91 \%$ of the teachers in national schools agreed that physical punishment has negative impacts. While majority, $72 \%$ of the teachers in international schools disagreed that physical punishment keeps discipline, $48 \%$ of the teachers in national schools supported the statement and $46 \%$ rejected it. Only $24 \%$ of the teachers in international schools supported the statement. This shows that many teachers in the two categories of schools are aware that some times physical punishment may not keep discipline. However, in national schools, the views are divergent; agreement and disagreement are on an average point. The table indicates that although $43 \%$ of the teachers in national schools agreed that physical punishment is a good corrective measure, $52 \%$ of the teachers in international schools agreed that physical punishment has negative impacts. This means that some teachers in national schools do not appreciate the use of physical punishment and negative impacts are not recognized by the majority of the teachers in international schools.

\section{$<$ Table 4 about here>}

The statement about dismissal of a teacher who beats children was supported by $56 \%$ of the teachers in international schools and was rejected by $77 \%$ of the teachers in national schools. Only $27 \%$ in national schools agreed with this statement while $32 \%$ of the teachers in international schools disagreed with the statement. This means that teachers in 
international schools do not like colleagues who physically punish pupils, but in national schools teachers encourage their colleagues to physically punish pupils.

As Table 5 indicates, majority (82.9\%) of the pupils in national schools agreed that physical punishment is a good corrective measure and many (59\%) of them disagreed that physical punishment has negative impacts. In international schools, majority, $71 \%$ of the pupils agreed that physical punishment has negative impacts and $68 \%$ of them disagreed that physical punishment is a good corrective measure. This shows that in the two categories of schools, pupils had divergent views with regard to the impact of this punishment and its effectiveness.

$<$ Table 5 about here>

In national schools, majority (98.6\%) of the pupils agreed that physical punishment keeps discipline but in international schools, majority (65\%) of the pupils disagreed with the statement. This means that pupils in national schools know that it is only physical punishment which can keep them disciplined while in international schools; physical punishment leads to rebellion and more vandalism. This could be the reason why dismissal of a teacher who beats children was not supported by the majority of the pupils in national schools. The statement on dismissal was rejected by $74.3 \%$ in national schools. However dismissal of a teacher who beats children was not supported by many pupils, even in international schools. In these schools, it was almost in average point; $48 \%$ of the pupils agreed and $44 \%$ disagreed. This shows that in national schools, pupils do not wish dismissal of their teachers even if they could physically punish them.

Majority (74.3\%) of the pupils in national schools did not wish abolition of physical punishment in schools while in international schools $48 \%$ of the pupils supported abolition of physical punishment. The results indicate that majority of the pupils in national schools do not wish abolition of physical punishment; that even in international schools, abolition of physical punishment is not the wish of the majority of the pupils.

When parents were asked whether their children have ever been punished by the schools, $57 \%$ of the parents in national schools and $48 \%$ in international schools said that their children were subjected to physical punishment. In international schools, $52 \%$ of the parents said their children were not subjected to physical punishment (see graph 1). This means that while use of physical punishment in schools is known by the majority of the parents in national schools, majority of the parents in international schools are not aware of the fact.

Parents and teachers were asked whether physical punishment should continue in schools. As shown in Table 6, the following responses were given: First, majority of the parents from international schools preferred physical punishment abolished and this was reported by $80 \%$. Second, parents who wanted the use of physical punishment were more in national schools $(63 \%)$. Although parents in international schools did not support total abolition of physical punishment, these observations have indicated that parents in national schools prefer the use of physical punishment on their children than other corrective means. Similarly, majority of the teachers in international schools (72\%) wanted the use of physical punishment to stop while in national schools, $57 \%$ of the teachers preferred continuation of physical punishment in schools.

\section{$<$ Table 6 about here>}

Pupils were asked to state punishments to which they were subjected. Pupils in international schools did not identify any physical punishment while pupils in national schools, caning as physical punishment was stated by $26.6 \%$ of the pupils; other punishment such as kneeling, quoted by $23 \%$, digging, identified by $14.2 \%$, crawling, carrying heavy objects, hanging, pulling ears, boxing, and kicking were physical abuse.

\section{$<$ Table 7 about here>}

As indicated in Table 8, parents suggested alternative forms to physical punishment. While $43 \%$ of the parents in national schools did not want any alternative form to physical punishment, $20 \%$ of them preferred detention, and $14.3 \%$ suggested counseling and guidance. On the other hand, $28 \%$ of the parents in international schools suggested withdrawal of privileges, $20 \%$ suggested detention, and $20 \%$ suggested exclusion from school. Withdrawal of privileges, detention, and cleaning the class room were commonly suggested by the parents of the two categories of schools.

\section{<Tables 8 \& 9 about here>}

Teachers were also asked to suggest alternative to physical punishment. The results showed that in international schools, preference of teachers is for guidance and counseling identified by $24 \%$. In national schools, $25.7 \%$ of the teachers identified giving more work. Withdrawal of privileges, parental involvement and punishment discussed by the class were each preferred by $16 \%$ of the teachers in international schools. Detention, counseling and guidance, and parental involvement were commonly suggested by the teachers in both international and national schools. In international schools, $20 \%$ of the pupils suggested the use of disciplinary book. These suggestions are found in Table 9. 
In national schools, $19.1 \%$ of the pupils suggested detention, $14.3 \%$ suggested exclusion from school, and $12.4 \%$ of the pupils suggested reward of good behaviour.

$<$ Table 10 about here>

In Table 11 it is shown that majority of administrators (64\%) in international schools reported that physical punishment was not administered in their schools due to the school policy prohibiting it. There was no response on school policy from national schools but rather, government initiative to forbid. This was reported by $34.3 \%$ of the administrators in national schools. This could be because many national schools mainly follow government policies where schools do not initiate policies.

\section{$<$ Table 11 about here>}

In addition, administrators said that physical punishment is not used in their schools because it is a form of child aggression. This was reported by $24 \%$ of the administrators from international schools while $28.6 \%$ of the administrators in national schools said physical punishment is not used because it leads students to dropouts of school. Few school administrators in national schools reported that physical punishment is not used in their schools because it causes injuries; others said that physical punishment is not used because it creates hypocrisy in children. These statements were respectively raised by $14.3 \%$ and $8.5 \%$ of administrators in national schools.

In international schools physical punishment is not used because they want to observe human rights. Data actually showed that governments forbid physical punishments.

These results show that use of physical punishment is avoided because of psychological (aggression, hypocrisy), social (violation of human rights), physical (injuries), school attendance (dropouts) consequences and judicial (national laws) regulations. Some governments do not allow the teachers to physically punish pupils.

When asked whether physical punishment should continue, administrators in international schools did not answer. However, $37 \%$ of the administrators in national schools responded affirmatively and the majority, $63 \%$ responded that it should not continue. Since those administrators who reported that physical punishment should continue were all from national schools, they were asked reasons for continuation.

Table 12 shows that in national schools $28.6 \%$ of the administrators reported that physical punishment should continue because it makes pupils understand quickly, 23\% said that physical punishment improves academic performance, $20 \%$ responded that simple words do not help African children, therefore use of physical punishment should continue. Referring to the Ugandan tradition on corrective measures, a small number of the administrators $17.1 \%$ reported that physical punishment should continue because it was in use since ancient times in Uganda, and for others (11.3\%), physical punishment should continue because it is allowed by the Bible.

$<$ Tables 12 about here>

These results show that all the responses given by administrators in national schools supported the practice. These responses were given in accordance with their daily experience.

Table 13 shows what school administrators responded to the interview requesting them to suggest alternative forms of punishment;

a) In international schools, (28\%), of school administrators suggested exclusion from school and $20 \%$ of them suggested reprimands. Others were detention (16\%), public and written apology by the wrongdoer (12\%) and parental involvement (12\%);

b) In national schools, administrators suggested also exclusion from school (8.6\%) a written public apology (22.6\%), guidance and counseling (22.9\%), parental involvement (16.5\%) and sending the culprit outside the classroom (8.6\%).

Exclusion from school, detention, sending the culprit out of the classroom, apology and parental involvement were alternative punishments commonly suggested by school administrators. This means that administrators in the two categories of schools have the same feelings on corrective measures. However, exclusion from school is more bitter and expensive than a caning stroke. Sending a lazy child out of the classroom is giving him/her a good time of relaxing and enjoy; so is detention. About parental involvement, findings have shown that even parents have failed to warn their children. In addition, some parents are very weak (have lost authority) towards their children. Concerning guiding and counseling and warning many parents have realized the warnings have failed in many families; nowadays guiding and counseling are being challenged because in many ways children are getting more influenced by outside children and find that guidance and counseling are annoying statements.

\section{$<$ Table 13 about here>}




\section{Interpretation}

This chapter is concerned with interpretation of the research findings. The chapter indicates how the data were collected, provides explanations, views of other researchers, discussions and opinion the researcher.

This study explored the views of stakeholders through a Likert scale. The findings exposed that views towards physical punishment were divergent between parents in international schools and those in national schools. On a whole, the findings revealed that parents agreed that physical punishment has negative impacts. In fact, majority of the parents in international schools disagreed that physical punishment is a good corrective measure; they also disagreed that it keeps discipline. These findings are in agreement with the findings established by Suda (2005), Docking (1980:46) and Seburimage (1998) arguing that physical punishment leads to more vandalism, truancy, pupil violence and a higher drop out rate; that children who get spanked are more likely to lie, to be disobedient at school, and to bully others; that schools that practice caning seem to have a higher delinquency rate leading to rebellion and aggressiveness; that students resist caning and other forms of disciplinary actions alike for correcting them and tend to organize strikes.

The findings revealed that majority of the parents in the two categories of schools disagreed that a teacher who beats children should be dismissed from school. These findings concur with the findings of Human Rights Watch (1999) that in Kenya, parents did not want teachers who physically punish pupils to be dismissed from school even if the child is injured; that this being an accident it may also happen at home.

The findings of this research showed that in the extreme, parents in international schools were of the view that physical punishment should be abolished, while the parents in national schools were in disagreement with the abolition of physical punishment because they still find it as a good corrective measure. Parents who wanted physical punishment to be abolished in schools were more in international schools than in national schools while parents who did not support abolition of physical punishment in schools were more in national schools than in international schools.

In the same line, the Eastern and Southern African Report (2005), Naker (2005), Eremu (2004: 29), Zinjah (2004), Kakovina (2002 and Nagawa (1998) established that physical punishment is not a humiliation but it is needed; that physical punishment should remain because it protects and guides children, parents wanted physical punishment to continue in schools because it is useful in the sense; that physical punishment guides children and leads them to change bad behavior, physical punishment should remain because its abolition was responsible for poor performance; that a supervised caning as a disciplinary measure was fine, physical punishment should resume and should not be abolished, abolishing physical punishment in schools would be a hindrance to maintain discipline; that corporal punishment is cheap and easy to administer, it is always available, physical punishment elicits quick response and requires little intelligence; that corporal punishment is straight forward and logically acceptable compared to other types of punishment. In addition, African scholars and writers believe that physical punishment is appropriate to their children.

However, it is not proved that all African children subjected to physical punishment behave in an expected manner or perform very well. When physical punishment is used in anger, it becomes physical abuse; obviously, it must impact negatively. In these circumstances it will cause injures, and in the worse, death. Undisciplined children will hate the teacher but physical punishment in its broader meaning, it keeps discipline in class. The teacher should not be dismissed from school when he/she physically punishes but needs to be advised on the use of physical punishment. In any way, physical punishment should not be abolished in schools but encouraged. Physical abuse of course is to be abolished because it is not an educative one or counter-productive; in the contrary it is a torture.

Through a Likert scale, as applied to the teachers' responses, the findings of this research indicated that majority (91\%) of the teachers in national schools agreed that physical punishment has negative impacts and majority of the teachers in the two categories of schools agreed that physical punishment does not keep discipline. In national schools, majority of the teachers disagreed that a teacher who beats children should be dismissed from school, what many teachers in international schools agreed with and many of them agreed that physical punishment is a good corrective measure. The findings also showed that the abolition of physical punishment in schools was favoured by the majority of the teachers in international schools while majority of the teachers in national schools did not support abolition of physical punishment.

In the same point of view Block (2004), Fournier (2004), Eremu (2004), Yancy (1991), Docking (1986), Nagawa (1998 and Walter (1949) revealed that teachers complain because physical punishment was banned, abolition of physical punishment led to serious decline in school discipline; detentions and suspensions failed, teachers wanted physical punishment to resume in order bringing back the kind of discipline needed; in education, spanking should not be an isolated measure; corporal punishment is effective and is the best because it is the only punishment feared by the students; in primary and secondary schools in Yorkshire, $89 \%$ of the teachers were against the total abolition of corporal punishment in schools, teachers were advised to turn to physical punishment if they worked in an environment 
where the punishment was acceptable; children are spoiled by too much discipline, freedom and license to do what ever they wanted; Ugandan teachers have complain that the ban on caning had made enforcing discipline very difficult because the students are now rebellious and treat the punishment as an assault, teachers said that banning caning would be giving a license to students to even challenge other forms of punishment; guided caning, as a form of corrective measure should remain because caning is the most convenient and quickest form of punishment and is feared; other forms of punishment were time consuming, difficult to administer and did not have the desired deterrent impact; abolishing physical punishment could be a hindrance to maintaining discipline.

Objection to these statements is that supporters of physical punishment should not believe that the use of physical punishment is always the last solution to curb children's lives. Docking (1986) demonstrated that excellent behaviours do not depend on physical punishment; in the contrary, schools that practice caning seem to have a higher delinquency rate leading to rebellion and aggressiveness.

Abolition of physical punishment in schools was supported by the majority, $60 \%$ of the teachers in international schools and by only $40 \%$ of the teachers in national schools. In national schools, many teachers, (57\%) did not support abolition of physical punishment. These results show that abolition of physical punishment is supported by the majority of the teachers in international schools but by few teachers in national schools. This is because teachers in international schools follow carefully school policies that forbid the use of physical punishment; also, these teachers have negative conception of physical punishment. They know that in Western countries whoever beats a child is jailed. This is not the case for the parents and teachers in African national schools.

Literature quoting teachers who wish abolition of physical punishment, especially from national schools, is rare. It seems that teachers are imposed to stop the punishment against their willingness; these are governments which do not have implemented policies on the use of physical punishment. This may be one of the reasons which lead teachers not totally abide the dictatorial law abolishing physical punishment without the teacher's consent. Teachers are the ones who interact daily with the students. Therefore, abolishing the punishment against their willingness will be wrong and these will always claim it to resume. Teachers are the ones who know what is happening on the ground. In Africa especially, teachers will never unanimously abide laws forbidding physical punishment.

Teachers are the ones experiencing what is happening in class with the children. Therefore, their remarks should be taken into account. Once again, a teacher should not be dismissed for having caned a pupil. In any way, a good teacher cannot say that physical punishment should be abolished. Punishing physically is one of professional life of a teacher.

Using a Likert scale, the findings further revealed the views of pupils towards physical punishment where majority of the pupils in national schools were in agreement that physical punishment is a good corrective measure, but majority of pupils in international schools disagreed with the statement. Majority of pupils in international schools agreed that physical punishment has negative impacts. In the two categories of schools, pupils had divergent views on the impacts of physical punishment. In national schools majority of pupils agreed that physical punishment keeps discipline while in international schools majority of the pupils disagreed with this statement. The dismissal of a teacher who beats children was not supported by the majority of the pupils in national schools. Majority of pupils in national schools were in disagreement with abolition of physical punishment.

These findings meet the intention of Yancy (1991), Fournier (2004), Dobbs (2004), Leggett (2000:1) (Block, 2004) and Starr (2002) reporting that students said that corporal punishment is effective because it makes students to wonder and avoid the swat; that the absence of spanking in childhood negatively affects the child's discipline and makes him a disoriented man who lacks some landmarks in his present life; that sometimes, when a child is smacked, only his trousers feel the pains; that parents should not be yelling and hitting them even if they are naughty; that Ugandan students did not like UPE because teachers were punishing them a lot.

In the two categories of schools, pupils agreed that physical punishment has negative impacts; this is true in the sense that they are the ones subjected to the punishment; they are the ones who are injured when physically abused; they are the ones who appreciate which kind of punishment is appropriate in its use. It is obvious for the majority of the pupils in international schools to disagree that physical punishment is a good corrective measure. These children are not used to this kind of punishment from their families; in the families of pupils from national schools, physical punishment is a habit. Literature has shown that in the worse, children from western families can shoot their parents, teachers or peers when they make them uncomfortable.

Physical punishment cannot keep discipline when it is misconceived by the children; in this situation, their only option would be abolition of physical punishment. But it seems that in recent days, both parents and students from western families have understood that physical punishment is important. That is why in the two categories of schools children 
did not agree that a teacher who beats children should be dismissed. Corporal punishment is therefore the most effective disciplining tool. For these stakeholders, the absence of physical punishment disorients the child and leads him/her to lack landmarks in his/her life. This means that while some children in Western countries do not appreciate the use of physical punishment, others appreciate it. However, it is not very sure that a paddled student improves the behavior. The findings of Docking, (1998) showed that some pupils become violent when they are physically punished.

About continuation of physical punishment, the general observation was that majority of the parents in international schools were not in favour of the continuation of physical punishment but in national schools, majority of the parents were in favour of its continuation. Correspondingly, majority of the teachers in international schools were not in favour of continuation of physical punishment. The findings revealed that the bigger number of the teachers in international schools did not want physical punishment to continue in schools. The findings concur with the findings of (Bunty, 1998) Nagawa, 1998), (Kakovina, 2002), Block, 2004) and the Eastern and Southern African Report (2005) supporting that physical punishment as a means of guiding the child should continue if it is not used as a physical abuse. In physical punishment, government regulations indicate the number of strokes to be administered in accordance with the mistake done by the pupil.

Among punishments quoted by the pupils, most of them are physical abuse; only caning was physical punishment. Caning is physical punishment because it is used for correcting the pupil and is somehow regulated by many governments. On the other hand, kneeling, digging, crawling, carrying heavy objects, hanging on the wall and the ground, pulling the ears, boxing, and kicking are on the line of physical abuse because they make the child suffer rather than making the child experience pain in order to correct him/her. In addition, these kinds of punishment are not regulated anywhere by governments. This indicates that pupils in national schools are mostly subjected to physical abuse than physical punishment. Use of physical punishment should be applied in agreement with the child in a loving manner (for example, "how many strokes do you want me to hit you?"). Physical punishment should be used with dialogue between the offender and the actor; the wrongdoer has the right to know the reason of the punishment and has to accept it. Therefore, physical punishment is to be used with the consent of the child in order to create remorse in him/her. Parents and teachers should not show children their anger because of child's misbehaviour but show them that the punishment is for his/her own help; they should feel sorry and lovely with the child when he/she commits mistakes. Physical punishment can only have sense or resume when this condition is fulfilled.

The findings of this research revealed that withdrawal of privileges, exclusion from school, blame, sending the culprit to the Head teacher's office, guidance and counseling, parental involvement, standing position in the class room were suggested by the parents. These findings are in line with the findings established by Human Rights Watch (1999), the South African Operational Management (2002), Sanderson (1996) suggesting teacher's denial of what the student wanted, pupil's exclusion from school, rebuke, involvement of the Superintendent and the school Principle, guidance and counseling, parental warm; they also suggested that a disruptive pupil should sit on the chair in front of the classmates, on a mat, or at the back of the classroom.

However, $43 \%$ of the parents from national schools responded that there should not be alternative forms to physical punishment. In the same view, Naker (2005), Zinjah (2004), Eremu (2004), Kekovina (2002) reported that $87.9 \%$ of the Ugandan parents said that physical punishment is useful; that caning of children should not be forbidden, that caning should remain. Bunty's (1998) findings revealed that physical punishment should be brought back to school because pupils laugh at detention and Eremu added that other punishments are time consuming. Findings have shown that even in international schools, physical punishment is currently needed.

However, refusal of any alternative form of physical punishment is also another weakness. There are punishments which have the same weight as physical punishment has. Withdrawal of privileges is among the serious punishments that apply for alternative to physical punishment. Another serious punishment is for example, to refuse a child to get his/her marks after the exam, or to refuse the culprit to sit a test. These punishments may lead other children to cease being disrupted.

Findings of this research revealed that teachers suggested counseling and guidance, parental involvement, withdrawal of privileges, punishment discussed with the class, use of peer influence, self-discipline, giving more class work, sending culprit to the Head teacher's office, written and public apology, exclusion, use of disciplinary book, and rewarding student's good behaviour as alternative forms to physical punishment.

These findings are in agreement with the findings established by Human Rights Watch (1999), the National Association of School Psychologists (2002), Sanderson (1996), the South African Operational Management (2003), Canady (1994) suggesting daily counseling and guidance, denial of what the student likes, calling the child's parent for parental warm, democratic discipline, involvement of small group to participate in the learning, use of peer mediators, focusing on pupils' success and self esteem, prevention of off-task behaviour and justice conference, 
additional class work, involvement of the Principle and Superintendent, statement writing and public apology by the wrongdoer, exclusion of the wrongdoer, writing good comments in the student's book, use of positive reinforcement.

The research findings have shown that most of teachers in both international and national schools had the practice of sending culprits to the Headmaster's office. Sending the child to the Head teacher's office would be a sign of weakness of the teacher. Thompson and Manion (1973) instructed that sending the offender to the Head teacher's office dilutes and weakens teacher's authority. Giving more work would be a way of keeping children busy so that they do not have time to disturb the teacher and their peers. Suggesting alternative forms does not imply abolition of physical punishment. According to Eremu (2004) and Block (2004), where one of these alternatives fails, then a guided and supervised physical punishment should be used in order to bring back the desired discipline. Most of alternative forms which were suggested by the teachers have more disadvantages than advantages but withdrawal of privileges is the best. Withdrawal of privileges, detention, exclusion from school, and the cleaning of school compound were punishment commonly suggested by the pupils of the two categories of schools.

These findings are in agreement with the findings of Human Rights Watch (1999), the National Association of School Psychologists (2002), the South African Operational Management (2003), Sanderson (1996), and Canady (1994) that writing good comments in the student's book, giving additional work, denying what the student wants, rebuking, doing positive reinforcement, involving the Principle, invitation of the parents, statement writing and apologizing in front of classmates and justice conference could be alternative forms of physical punishment. Their findings revealed that students said teachers should also reward them, especially for good behaviour and academic achievement; that caning is good but rewarding good students is very good.

The best alternative form is the withdrawal of privileges, without abolishing physical punishment. Donnelly and Murray (2005) stress that pupils are physically punished in schools to safeguard and promote their welfare. In the same point of view, some pupils who have ever been physically punished in their schools believed that physical punishment was helpful because of the positive change it brought in their lives.

This should be taken into account because pupils are the ones subjected to punishments; they are aware that when they are not busy, some of them create disorders in class; therefore, the teacher should give them more class work. Pupils in both international and national schools understand that when all kinds of psychological punishment have failed and when physical punishment is not in use, the last option is to exclude the obstinate peer who may disturb the entire class even the school.

It is not sure whether parental involvement will be a success. It has been observed that some parents have been overwhelmed by the indiscipline of their children and do not have any say in having them corrected. Some parents even say that warning systems have failed. This may be true even in international schools as well. For example, available literature has shown that it is international schools especially in Western countries where children threaten their parents with guns and other weapons. In this respect, parental involvement is not totally helpful. In the (New Vision, November $22^{\text {nd }}$, Bainomigisha (2004:29) established and reported that, in Uganda, cases of domestic violence, defilement, rape and assault are more reported to the police during holidays. These cases are rarely reported when students are at school.

This shows that teachers are more serious in disciplining children. Parents have failed to warn their children. On the other hand, some parents are very weak towards their children in the sense that they have lost authority. Punishing physically the child at school is to help the parents. Sending a lazy child out of the classroom is giving him/her a good time of relaxing and enjoy, so is detention. Exclusion from school is bitterer and more expensive than caning.

Parents, teachers and pupils in both international and national schools believed that class tasks could be taken as an alternative to physical punishment. In relation to some of these findings, Carol Natukunda (2006) suggested that schools should review their respective rules and introduce more professional and acceptable sanctions to replace manual labor and caning; that schools should record any disciplinary action in the punishment book indicating the type of offence and the respective type of punishment authorization but also the particulars of the person administering the punishment so that a regular system of records is maintained. This way of punishing has been also criticized by Thompson and Manion (1973) who warn that under no circumstances should school work be a punishment and also say that sending culprit out of the classroom does not help the child.

Self-discipline may be successful in condition that the school organizes various activities which could keep the child busy. However, self- discipline requires a lot of equipments to be used by each pupil; yet, national schools are not rich enough to equip their schools for this purpose. Rewarding, appraising are parts of positive reinforcement, but one cannot beg children to behave properly because children are there to be educated not to be caressed, said Fournier (2004). In 
addition, educational principles instruct that a reward should be rare; it should come at a convenient time, and should not be monotonous to keep its value.

\section{Conclusions}

The study has shown that stakeholders have had different attitudes and contradictory views regarding the use of physical punishment. Distinction between physical punishment and physical abuse is not clear among stakeholders.

The study showed that many parents $(43 \%)$ in national schools still prefer the practice of physical punishment on children. Physical punishment was not completely excluded in the mind of the pupils. The study revealed that in both international and national schools, pupils acknowledged that physical punishment is helpful; pupils did not agree that a teacher who beats children should be dismissed. This still shows that pupils have found physical punishment helpful. Referring to these findings it seems that pupils are driven by external pressures about the matter of the use of physical punishment. Findings have indicated that pupils in government schools are physically abused by their teachers rather than being physically punished.

Physical punishment has been badly conceived; some stakeholders give a bad picture to the punishment and this creates fear and hate in the child. Misunderstandings between stakeholders occur because the government of Uganda hasn't yet implemented policies to regulate use of punishment in Ugandan schools; what is known on the matter is only the Ugandan law and warnings in newspapers.

\section{Recommendations}

This study is an applied research which intended to find solutions for the problem of the use of physical punishment in schools. Then, the researcher suggested the following recommendations addressed to politicians, policy makers, education planners, school administrators, teachers, parents and NGOs working with children,

1) Policy makers are to focus on positive attitudes of physical punishment; they should give a good picture of the punishment in order to avoid misconception of physical punishment among children and the pupils.

-Respect to the teachers should, especially, be given by the Ugandan Ministry of Education and Sports, policy makers and other politicians in order to protect them and raise their respect towards the parents and pupils.

-Teachers should be advised by governmental authorities instead of being humiliated and threatened for dismissal through the media.

-The Ministry of Education should organise training on corrective measures which will be regularly supervised by specialists in education.

-During holidays, children's conferences should also be organised so that children are given opportunity to share ideas and experience on the matter; this should be supervised by schools.

- If policies and regulations on punishment are not yet implemented to solve the problem of approved and accepted corrective measures, it is now time to the Ugandan policy makers to establish alternative forms of physical punishment.

2) School administrators who are the first advisors of the teachers should collaborate with them and protect them against external intimidations.

-The Ugandan school administrators should follow the example of the Kenyan administrators who support their teachers against external complaints (school administrators simply tell the parents that whoever does not want his/her child to be caned should take the child to another school); this could increase respect of the Ugandan teachers.

3) Teachers should try alternative punishments until the use of physical punishment is regulated in Ugandan schools because punishment cannot only be corporal; it may also be social, emotional and mental.

-They should vary class activities to avoid pupils being bowered and become uncomfortable.

-Teachers should focus their attention on stubborn children because psychological researches have proved that stubborn children are more creative than the calm/ humble ones.

-As educators, teachers should continue to search for new ways of improving the quality of their schools despite some intimidations and threats from different categories of people.

4) Parents should exercise their authority on their children rather than telling the school to do the parents' work (give the first notions of discipline). Between exclusion of the culprit and caning, it is exclusion that should be the last resort; exclusion causes financial loss and creates strong emotion to both the pupils and the parents.

5) Since majority of administrators, parents and pupils in national schools did not support abolition of physical 
punishment, the Ugandan authorities should find ways of regulating it.

- Physical punishment should not totally be abolished because circumstances that lead pupils to be physically punished have demonstrated that physical punishment is for the safeguard and welfare of the child.

-Although physical punishment impacts negatively, the findings of this study revealed that majority of the parents and pupils did not wish dismissal of a teacher who beats children. This shows that in physically punishing pupils, teachers are aiming to help them.

6) NGOs working with children constitute consultative bodies; therefore they should advise all categories of stakeholders and keep a neutral position in the matter. The fact is that no one of the punishment is going to make all the pupils conform to the established rules. Too much freedom and too much discipline have the same effects in education (Walter, 1949).

Findings revealed that physical punishment was not totally disapproved by all stakeholders in the two categories of schools and it was not totally approved by all the stakeholders of the two categories of schools.

The study revealed that most of the pupils in Ugandan primary schools were mostly physically abused rather than being physically punished.

Although majority of stakeholders in international schools did not appreciate the use of physical punishment in schools, stakeholders of the two categories of schools did not clearly distinguish what should be considered as alternative to physical punishment.

Therefore, the researcher recommended that:

-Stakeholders should be trained (through seminars, workshops and conferences).

-The government of Uganda should implement regulations of punishments and alternative forms of physical punishment in Ugandan schools.

This is to say that Uganda government should provide guidelines to regulate administration of punishments in national schools as it is the case in other countries.

\section{References}

Bainemigisha, H. (2004). Whom to be blamed for indiscipline of children? The New Vision Printing Paper, Kampala.

Beth, W (1994). How parents should behave if they want children to behave well. UNICEF, New Zealand. Retrieved from http://www.onlineopinion.com.au/view.asp?article=1972, 2005.

Block, N (2004). Answers for parents. Center for effective discipline, Answers. Retrieved from http://www.stophitting.com/answers, 2005.

Bunty, W. (1998). Punitive corporal punishment in South Africa. Rushing to school not because they are keen but need a seat. Johannesburg. The Star. Retrieved from www.corpun.com, 2006.

Canady, J. (1994). School punishment alternative. Canady Foundation, London.

Cohen, L., \& Manion, L. (1997). A Guide to teaching practice, London: Methuen \& Company Ltd.

Docking, J.W.(1980) .Control and Discipline :Perspectives and Approaches .London: Hansek and Row.

Eremu, J (2004, December).Should caning be reintroduced ?.The New Vision, Kampala.

Eremu, J. (2004,September,20). Mugesha Byomuhendo warns against caning, Education Vision. The New Vision, p.37.Kampala.

Donnelly, S., \& Murray, A. (2005). Corporal punishment of children in the theoretical perspective, Theoretical approaches to corporal punishment, London: Yale University Press.

Fournier., J. L. (2004). Mouchons nos morveux, Pour ou contre la fessée, Livre de Poche Paris, SARI.

Government of Uganda. (1995). The Uganda Constitution. Kampala: Ugandan Parliament.

Government of Uganda. (2000). Children Act, Laws of the Republic of Uganda, Revised Edition. Kampala:Vol.3 cap59 Section 94 (9) .

Government of Uganda. (1992). Report of the Child law review committee (Annexes).Kampala: Government of Uganda. Government of Uganda (1995). White Paper, Kampala, Uganda Parliament. 
Hans, N. (1986). Comparative Education: A study of Educational factors and traditions. London, Routledge and Kegan Paul.

Human Rights Watch. (1999). Violence against children in schools, Children's Rights Division. Press Release.

Kakovina, C. (2002). Deprivation of Basic needs as a motivator for criminal activities among children. Save the children, UK.

Leggett, I. (2001). Uganda: Country Profile. Kampala: Oxfam.

Naker, D. (2005). Violence against children. The Voice of Ugandan Children and Adults: Raising Voice. Save the children, Uganda.

Mac, L, B. (2004). Corporal punishment still part of kid's Africa. Cape Argus, Cape Town.

Mararike, C. (2005). Spare the rod, save the child. IRIN, Johannesburg.

Mugemuzi, J. (2003, July, 16). Why caning is an issue. The New Vision. Kampala.

Nagawa, P.J(1998). Corporal punishment and Behavior of Primary School Pupils of Kampala District .Unpublished Masters Dissertation, Maker ere University, Uganda.

National Association of School Psychologists. (2002). Position statement on corporal punishment in schools. West Highway, Bethesda: National Association of School Psychologists

Natukunda, C. (2006,August,14). Caning banned in schools. The New Vision, Vol.21, No.194, p.1.

Operational Education Management. (2003). Discipline in School Government of the Western Cape. Education Department Provincial Government of the Western Cape.

Dobbs, T. (1999). Children's Voice on physical punishment. New Zealand and Australia. Retrieved from www.endcorporalpunishment.org, 2005.

Pimheiro, M. (2000). " Spare the rod, save the child”.IRIN, Johannesburg.

Sanderson, B. (1996). Alternatives to physical punishment. Retrieved from http://www.san.beck.org

Seburimage, D.M. (1998). Students' Discipline and Academic Performance in Kisoro District .Unpublished Masters Dissertation, Makerere University, Uganda.

Starr, L. (2005) Corporal punishment: Teaching violence through violence. The educators. Best Friends. Education World.

Retrieved from www.educationworld.com?a-issues/starrces/.sht.

Suda, G. (2001). Discipline in Schools: Physical punishment can harm child Psyche. www.world physical punishment.

Uganda Government. (1999).Uganda Primary School Curriculum, Kampala,Uganda National Curriculum Centre.

Walter, B.D. (1949).New Ways in Discipline .New York: Mc Graw Hill Book Company.

Wilson, R.M.C (2001). The study of education and childhood. Domestic corporal_punishment. London, England National Bureau.

Wilson, H. (1998). Feelings of children on physical punishment, Children talking on smacking, save the children, England National Bureau.

World Physical Punishment. (2006). Retrieved from http://www.socsci.kun.nl/ped/whp/histeduc/wilson02/html, 2006.

Yancy, T. (2006). Voluntary corporal punishment: Reduce suspension rates. Voluntary corporal punishment_html, 28September 2006.

Yodon, T.(1999). Corporal punishment in Kenyan schools: Spare the child. Vol.2, No 6A. Nairobi, 6A.

Zinjak, M., (2004,November,15).Education Vision. Restore caning-LC5. The New Vision. Kampala: Printing and Publishing Corporation Uganda.p.32. 
Table 1. Selection of schools in Kampala District

\begin{tabular}{|l|c|c|c|c|}
\hline \multirow{2}{*}{ DIVISIONS } & \multicolumn{2}{|c|}{ International Schools } & \multicolumn{2}{c|}{ National Schools } \\
\cline { 2 - 5 } & Number of Schools & School Selected & Number of Schools & School Selected \\
\hline Central & 3 & 2 & 6 & 5 \\
\hline Kawempe & - & - & 5 & 3 \\
\hline Makindye & 4 & 2 & 5 & 2 \\
\hline Nakawa & 3 & 2 & 5 & 3 \\
\hline Rubaga & - & - & $\mathbf{2 4}$ & $\mathbf{1 5}$ \\
\hline Total & $\mathbf{1 0}$ & $\mathbf{6}$ & & 2 \\
\hline
\end{tabular}

Table 2. Number of respondents

\begin{tabular}{|c|c|c|c|}
\hline CATEGORIES & International Schools & National Schools & Total \\
\hline School administrators & 25 & 35 & 60 \\
\hline Parents & 25 & 35 & 60 \\
\hline Teachers & 25 & 35 & 60 \\
\hline Pupils & 75 & 105 & 180 \\
\hline Total & 150 & 210 & 360 \\
\hline
\end{tabular}

Table 3. Views of the parents on physical punishment in schools

\begin{tabular}{|c|c|c|c|c|c|c|c|c|c|c|c|c|}
\hline \multirow{3}{*}{ ISSUES } & \multicolumn{6}{|c|}{ International Schools } & \multicolumn{6}{|c|}{ National Schools } \\
\hline & \multicolumn{2}{|c|}{$\mathbf{A}$} & \multicolumn{2}{|c|}{$\mathbf{D}$} & \multicolumn{2}{|c|}{$\mathbf{U}$} & \multicolumn{2}{|c|}{$\mathbf{A}$} & \multicolumn{2}{|c|}{$\mathbf{D}$} & \multicolumn{2}{|c|}{$\mathbf{U}$} \\
\hline & $\mathrm{N}$ & $\%$ & $\mathrm{~N}$ & $\%$ & $\mathrm{~N}$ & $\%$ & $\mathrm{~N}$ & $\%$ & $\mathrm{~N}$ & $\%$ & $\mathrm{~N}$ & $\%$ \\
\hline Physical punishment is a good corrective measure. & 4 & 16 & 20 & 80 & 1 & 4 & 21 & 60 & 11 & 31 & 3 & 9 \\
\hline Physical punishment has negative impacts. & 16 & 72 & 6 & 24 & 1 & 4 & 29 & 82 & 4 & 12 & 2 & 6 \\
\hline Physical punishment keeps discipline. & 5 & 20 & 20 & 80 & 0 & 0 & 8 & 22 & 24 & 69 & 3 & 9 \\
\hline A teachers who beats children must be dismissed from school. & 7 & 28 & 17 & 68 & 1 & 4 & 2 & 6 & 31 & 88 & 2 & 6 \\
\hline Physical punishment must be abolished in schools. & 16 & 64 & 8 & 32 & 1 & 4 & 13 & 37 & 19 & 54 & 3 & 9 \\
\hline
\end{tabular}

A=Agree; $\mathrm{D}=$ Disagree; $\mathrm{U}=$ Undecided;

$\mathrm{N}=$ Number of respondents (out of 25 in international schools and 35 in national schools). 
Table 4. Views of the teachers on physical punishment

\begin{tabular}{|c|c|c|c|c|c|c|c|c|c|c|c|c|}
\hline \multirow{3}{*}{ ISSUES } & \multicolumn{6}{|c|}{ International Schools } & \multicolumn{6}{|c|}{ National Schools } \\
\hline & \multicolumn{2}{|c|}{$\mathbf{A}$} & \multicolumn{2}{|c|}{$\mathbf{D}$} & \multicolumn{2}{|c|}{$\mathbf{U}$} & \multicolumn{2}{|c|}{$\mathbf{A}$} & \multicolumn{2}{|c|}{$\mathbf{D}$} & \multicolumn{2}{|c|}{$\mathbf{U}$} \\
\hline & $\mathrm{N}$ & $\%$ & $\mathrm{~N}$ & $\%$ & $\mathrm{~N}$ & $\%$ & $\mathrm{~N}$ & $\%$ & $\mathrm{~N}$ & $\%$ & $\mathrm{~N}$ & $\%$ \\
\hline Physical punishment is a good corrective measure. & 5 & 20 & 19 & 76 & 1 & 4 & 15 & 43 & 19 & 54 & 1 & 3 \\
\hline Physical punishment keeps discipline. & 6 & 24 & 18 & 72 & 1 & 4 & 17 & 48 & 16 & 46 & 2 & 6 \\
\hline Physical punishment has negative impacts. & 13 & 52 & 9 & 36 & 3 & 12 & 32 & 91 & 2 & 6 & 1 & 3 \\
\hline A teachers who beats children must be dismissed from school. & 14 & 56 & 8 & 32 & 3 & 12 & 6 & 17 & 27 & 77 & 2 & 6 \\
\hline Physical punishment must be abolished in schools. & 15 & 60 & 7 & 28 & 3 & 12 & 14 & 40 & 20 & 57 & 1 & 3 \\
\hline
\end{tabular}

$\mathrm{A}=$ Agree; $\mathrm{D}=$ Disagree; $\mathrm{U}=$ Undecided

$\mathrm{N}=$ Number of respondents (out of 25 in international schools and 35 in national).

Table 5. Views of the pupils on use of physical punishment in their schools

\begin{tabular}{|c|c|c|c|c|c|c|c|c|c|c|c|c|}
\hline \multirow{3}{*}{ ISSUES } & \multicolumn{6}{|c|}{ International Schools } & \multicolumn{6}{|c|}{ National Schools } \\
\hline & \multicolumn{2}{|c|}{$\mathbf{A}$} & \multicolumn{2}{|c|}{ D } & \multicolumn{2}{|c|}{$\mathbf{U}$} & \multicolumn{2}{|c|}{$\mathbf{A}$} & \multicolumn{2}{|c|}{ D } & \multicolumn{2}{|c|}{$\mathbf{U}$} \\
\hline & $\mathrm{N}$ & $\%$ & $\mathrm{~N}$ & $\%$ & $\mathrm{~N}$ & $\%$ & $\mathrm{~N}$ & $\%$ & $\mathrm{~N}$ & $\%$ & $\mathrm{~N}$ & $\%$ \\
\hline Physical punishment is a good corrective measure. & 10 & 13 & 51 & 68 & 14 & 19 & 87 & 82.9 & 14 & 13.3 & 4 & 3.8 \\
\hline Physical punishment has negative impacts. & 53 & 71 & 18 & 24 & 4 & 5 & 30 & 28.6 & 62 & 59 & 13 & 12.4 \\
\hline A teachers who beats children must be dismissed from school & 36 & 48 & 33 & 44 & 6 & 8 & 15 & 14.3 & 78 & 74.3 & 12 & 11.4 \\
\hline Physical punishment keeps discipline. & 17 & 23 & 49 & 65 & 9 & 12 & 93 & 98.6 & 9 & 8.5 & 3 & 2.9 \\
\hline Physical punishment must be abolished in sch & 36 & 48 & 33 & 44 & 6 & 8 & 15 & 14.3 & 78 & 74.3 & 12 & 11.4 \\
\hline
\end{tabular}

$\mathrm{A}=$ Agree; $\mathrm{D}=$ Disagree; $\mathrm{U}=$ Undecided

$\mathrm{N}=$ Number of respondents (out of 75 in international schools and 105 in national

Table 6. Parents and teachers' responses for continuation of physical punishment

\begin{tabular}{|l|c|c|c|c|c|c|c|c|}
\hline \multirow{3}{*}{ RESPONSES } & \multicolumn{4}{|c|}{ International Schools } & \multicolumn{4}{c|}{ National Schools } \\
\cline { 2 - 9 } & PARENTS & \multicolumn{2}{|c|}{ TEACHERS } & \multicolumn{2}{|c|}{ PARENTS } & \multicolumn{2}{|c|}{ TEACHERS } \\
\cline { 2 - 9 } & $\mathrm{f}$ & $\%$ & $\mathrm{f}$ & $\%$ & $\mathrm{f}$ & $\%$ & $\mathrm{f}$ & $\%$ \\
\hline Should continue & 4 & 16 & 7 & 28 & 22 & 63 & 20 & 57 \\
\hline Should not continue & 20 & 80 & 18 & 72 & 13 & 37 & 15 & 43 \\
\hline Not sure & 1 & 4 & 0 & 0 & 0 & 0 & 0 & 0 \\
\hline \multicolumn{1}{|c|}{ Total } & $\mathbf{2 5}$ & $\mathbf{1 0 0}$ & $\mathbf{2 5}$ & $\mathbf{1 0 0}$ & $\mathbf{3 5}$ & $\mathbf{1 0 0}$ & $\mathbf{3 5}$ & $\mathbf{1 0 0}$ \\
\hline
\end{tabular}


Table 7. Some of the punishments pupils are subjected to

\begin{tabular}{|l|c|c|c|c|}
\hline \multirow{2}{*}{ PUNISHMENTS } & \multicolumn{2}{c|}{ International Schools } & \multicolumn{2}{c|}{ National schools } \\
\cline { 2 - 5 } & $\mathrm{f}$ & $\%$ & $\mathrm{f}$ & $\%$ \\
\hline Caning & 0 & 0 & 28 & 26.6 \\
\hline Kneeling & 0 & 0 & 24 & 23 \\
\hline Digging & 0 & 0 & 15 & 14.2 \\
\hline Crawling & 0 & 0 & 12 & 11 \\
\hline Carrying heavy objects & 0 & 0 & 10 & 9 \\
\hline Hanging* & 0 & 0 & 6 & 5.7 \\
\hline Pulling ears & 0 & 0 & 6 & 5.7 \\
\hline Boxing & 0 & 0 & 2 & 1.9 \\
\hline Kicking & 0 & 0 & 2 & 1.9 \\
\hline & $\mathbf{0}$ & $\mathbf{0}$ & $\mathbf{1 0 5}$ & $\mathbf{1 0 0}$ \\
\hline
\end{tabular}

*Hanging means hands on the ground and feet on the wall.

Table 8. Parents' responses on alternative punishments

\begin{tabular}{|l|c|c|c|c|}
\hline \multirow{2}{*}{ ALTERNATIVE FORMS OF PUNISHMENT } & \multicolumn{4}{|c|}{ PARENTS } \\
\cline { 2 - 5 } & International & \multicolumn{2}{|c|}{ National } \\
\cline { 2 - 5 } & $\mathrm{f}$ & $\%$ & $\mathrm{f}$ & $\%$ \\
\hline Withdrawal of previleges & 7 & 28 & 1 & 2.9 \\
\hline Detention & 5 & 20 & 7 & 20 \\
\hline Exclusion from school & 5 & 20 & 0 & 0 \\
\hline Blame & 3 & 12 & 0 & 0 \\
\hline Cleaning the classroom & 3 & 12 & 2 & 5.7 \\
\hline Sending the culprit out of class the class room & 2 & 8 & 0 & 0 \\
\hline Sending culprits to the Head teacher's office & 0 & 0 & 1 & 2.9 \\
\hline Counselling and guidance & 0 & 0 & 5 & 14.3 \\
\hline Parental involvement & 0 & 0 & 1 & 2.9 \\
\hline Standing position in class & 0 & 0 & 1 & 2.9 \\
\hline No alternative & 0 & 0 & 15 & 43 \\
\hline Good teaching methods & $\mathbf{2 5}$ & $\mathbf{1 0 0}$ & $\mathbf{3 5}$ & $\mathbf{1 0 0}$ \\
\hline \multicolumn{1}{|c|}{ Total } & 0 & 2 & 5.7 \\
\hline
\end{tabular}


Table 9. Responses of teachers on alternative form of punishments

\begin{tabular}{|l|c|c|c|c|}
\hline \multirow{2}{*}{ ALTERNATIVE FORMS OF PUNISHMENT } & \multicolumn{5}{|c|}{ TEACHERS } \\
\cline { 2 - 5 } & International & \multicolumn{3}{|c|}{ National } \\
\cline { 2 - 5 } & $\mathrm{f}$ & $\%$ & $\mathrm{f}$ & $\%$ \\
\hline Counseling and guidance & 6 & 24 & 2 & 5.7 \\
\hline Withdrawal of privileges & 4 & 16 & 0 & 0 \\
\hline Parental involvement & 4 & 16 & 2 & 5.7 \\
\hline Punishment discussed with the class & 4 & 16 & 0 & 0 \\
\hline Use of peer influence & 3 & 12 & 0 & 0 \\
\hline Detention & 2 & 8 & 3 & 8.6 \\
\hline Use of means for self-discipline & 2 & 8 & 0 & 0 \\
\hline Giving more class work & 0 & 0 & 9 & 25.7 \\
\hline Sending culprit out of the class the class room & 0 & 0 & 4 & 11.4 \\
\hline Sending culprits to the Head teacher's office & 0 & 0 & 4 & 11.4 \\
\hline Public and written apology by the culprits & 0 & 0 & 3 & 8.6 \\
\hline Exclusion from school & 0 & 0 & 3 & 8.6 \\
\hline Cleaning the class room & 0 & 0 & 2 & 5.7 \\
\hline Use of disciplinary book & 0 & 0 & 2 & 5.7 \\
\hline Reward good behaviour & 0 & 0 & 1 & 2.9 \\
\hline \multicolumn{1}{|c|}{ Total } & $\mathbf{2 5}$ & $\mathbf{1 0 0}$ & $\mathbf{3 5}$ & $\mathbf{1 0 0}$ \\
\hline
\end{tabular}

Table 10. Responses of pupils on alternative forms of punishment

\begin{tabular}{|l|c|c|c|c|}
\hline \multirow{2}{*}{ ALTENATIVE FORMS OF PUNISHMENT } & \multicolumn{5}{|c|}{ PUPILS } \\
\cline { 2 - 5 } & International & \multicolumn{2}{|c|}{ National } \\
\cline { 2 - 5 } & $\mathbf{f}$ & $\mathbf{\%}$ & $\mathbf{f}$ & $\mathbf{\%}$ \\
\hline Use of disciplinary book & 15 & 20 & 0 & 0 \\
\hline Cleaning the classroom & 10 & 13 & 0 & 0 \\
\hline Giving more class work & 10 & 13 & 0 & 0 \\
\hline Cleaning the school compound & 10 & 13 & 10 & 9.5 \\
\hline Withdrawal of privileges & 8 & 11 & 12 & 11.4 \\
\hline Sending culprits to the Head teacher's office & 5 & 7 & 0 & 0 \\
\hline Detention & 3 & 4 & 20 & 19.1 \\
\hline Exclusion from school & 3 & 4 & 15 & 14.3 \\
\hline Warning system & 3 & 4 & 0 & 0 \\
\hline Blame & 0 & 0 & 7 & 6.7 \\
\hline Counselling and guidance & 0 & 0 & 8 & 7.6 \\
\hline Parental involvement & 0 & 0 & 12 & 11.4 \\
\hline Use of rewards for good behaviour & 0 & 0 & 13 & 12.4 \\
\hline Public and written apology by the wrong pupil & 0 & 0 & 8 & 7.6 \\
\hline & $\mathbf{7 5}$ & $\mathbf{1 0 0}$ & $\mathbf{1 0 5}$ & $\mathbf{1 0 0}$ \\
\hline
\end{tabular}


Table 11. Administrators' reasons why their teachers do not use physical punishment in their schools

\begin{tabular}{|l|c|c|c|c|}
\hline \multirow{2}{*}{ REASONS } & \multicolumn{2}{c|}{ International Schools } & \multicolumn{2}{c|}{ National Schools } \\
\cline { 2 - 5 } & $\mathrm{f}$ & $\%$ & $\mathrm{f}$ & $\%$ \\
\hline School policies do not allow the use of physical punishment & 16 & 64 & 0 & 0 \\
\hline Physical punishment is an aggression to the child & 6 & 24 & 0 & 0 \\
\hline Physical punishment is a violation of human rights & 3 & 12 & 5 & 14.3 \\
\hline $\begin{array}{l}\text { Physical punishment is forbidden by the Ugandan } \\
\text { Government }\end{array}$ & 0 & 0 & 12 & 34.3 \\
\hline Physical punishment leads to drop outs & 0 & 0 & 10 & 28.6 \\
\hline Physical punishment causes injuries & 0 & 0 & 5 & 14.3 \\
\hline Physical punishment creates hypocrisy in children & 0 & 0 & 3 & 8.5 \\
\hline \multicolumn{1}{|c|}{ Total } & $\mathbf{2 5}$ & $\mathbf{1 0 0}$ & $\mathbf{3 5}$ & $\mathbf{1 0 0}$ \\
\hline
\end{tabular}

Table 12. Administrators' reasons for continuation of physical punishment in schools

\begin{tabular}{|l|c|c|}
\hline \multirow{2}{*}{ REASONS } & \multicolumn{2}{c|}{ National Schools } \\
\cline { 2 - 3 } & $\mathrm{f}$ & $\%$ \\
\hline Physical punishment makes the pupil understand quickly & 10 & 28.6 \\
\hline Physical punishment improves academic performance & 8 & 23 \\
\hline Simple words do not help an African child & 7 & 20 \\
\hline Everybody in Uganda was physically punished & 6 & 17.1 \\
\hline Physical punishment is encouraged by the Bible & 4 & 11.3 \\
\hline Total & $\mathbf{3 5}$ & $\mathbf{1 0 0}$ \\
\hline
\end{tabular}

Table 13. Alternative form of punishment according to school administrators

\begin{tabular}{|l|c|c|}
\hline \multicolumn{1}{|c|}{ Punishment } & \% in International Schools & \% in National Schools \\
\hline Excusion from school & 28 & 8.6 \\
\hline Repriments & 20 & 0 \\
\hline Detention & 16 & 22.9 \\
\hline Public and written appology & 12 & 16.5 \\
\hline Parental involvement & 12 & 8.6 \\
\hline Sending the culprit outside the classroom & 4 & 0 \\
\hline Giving more classwork & 4 & 6.2 \\
\hline Sending the culprit to the Head teacher's office & 0 & 5.7 \\
\hline Use of reward for good behaviour & 4 & 22.9 \\
\hline Counselling and guidance & 0 & $\mathbf{1 0 0}$ \\
\hline \multicolumn{1}{|c|}{ Total } & $\mathbf{1 0 0}$ & \\
\hline
\end{tabular}




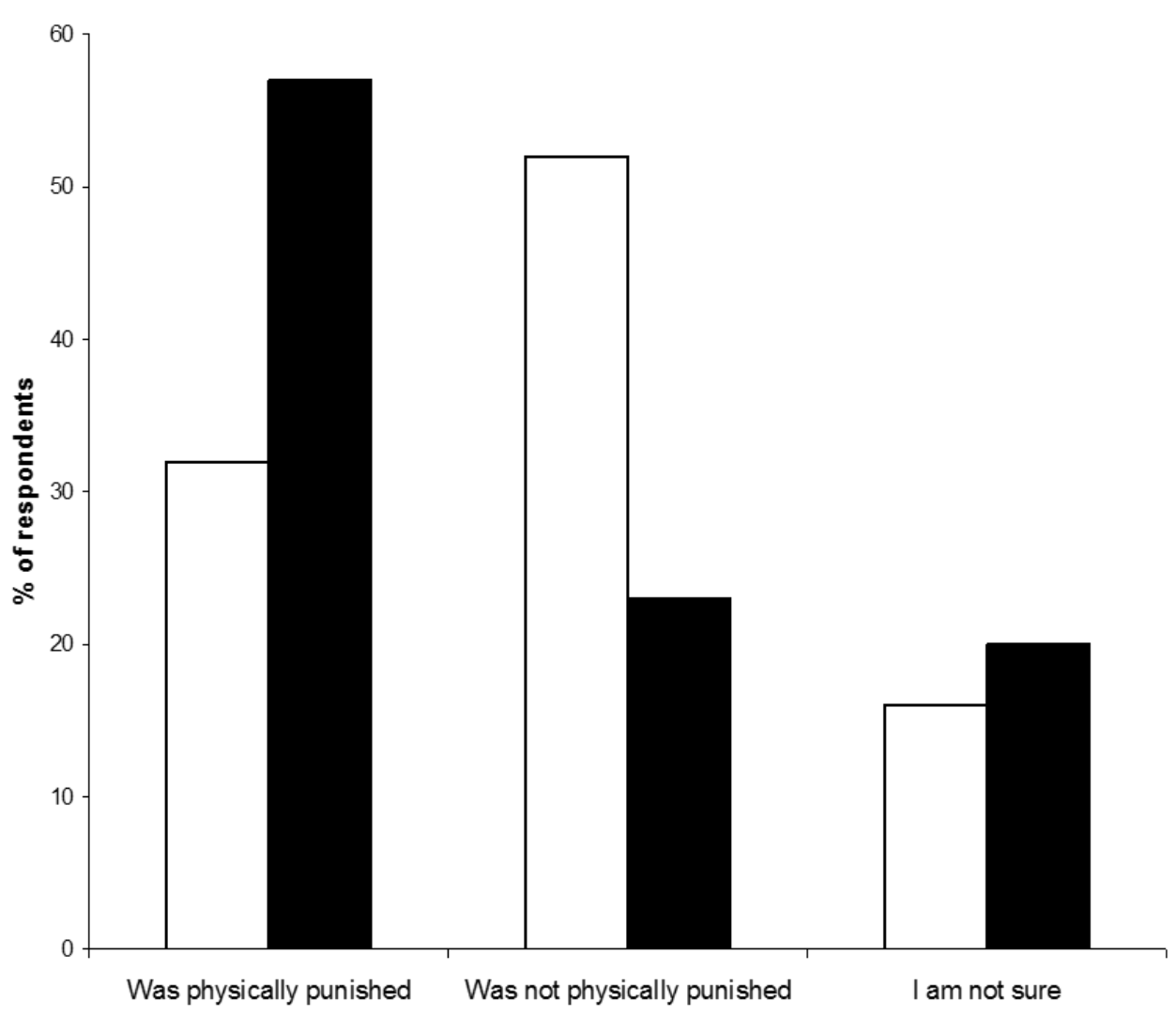

Figure 1. Responses from parents on awareness of punishment of children

Appendix 1: Questionnaire for Parents INSTRUCTION.

Dear Parent,

You are requested to answer the following questions. There is no right or wrong answer; what is important is your opinion/view on the issue raised. Response given will be treated with a high level of confidentiality.

1. Answer the following assertions by $\mathrm{A}=\mathrm{Agree}, \mathrm{D}=\mathrm{Disagree}, \mathrm{U}=\mathrm{Undecided}$.

i) Physical punishment is a good corrective measure.....

ii) Physical punishment has negative impacts......

iii) Physical punishment should be abolished (banned) in schools......

iv) Physical punishment keeps discipline in school........

v) A teacher who beats children must be dismissed from school.....

2. Do you think physical punishment should continue in Ugandan schools?

Tick one. Yes No

3. Suggest alternative to physical punishment.

THANK YOU. 
Appendix 2: Questionnaire for Teachers INSTRUCTION.

Dear Teacher,

You are requested to answer the following questions. There is no right or wrong answer; what is important is your opinion/view on the issue raised. Response given will be treated with a high level of confidentiality.

1. Answer the following assertions by $\mathrm{A}=$ Agree, $\mathrm{D}=$ Disagree, $\mathrm{U}=\mathrm{Un}$ decided.

i) Physical punishment is a good corrective measure.......

ii) Physical punishment has negative impacts........

iii) Physical punishment should be abolished (banned) in schools.......

iv) Physical punishment keeps discipline in school......

v) A teacher who beats children must be dismissed from school......

2. Do you think physical punishment should continue in Ugandan schools?

3. Suggest alternative to physical punishment.

THANK YOU.

Appendix 3: Questionnaire for Pupils INSTRUCTION

Dear Pupil,

You are requested to answer the following questions. There is no right or wrong answer; what is important is your opinion/view on the issue raised. Response given will be treated with a high level of confidentially.

1. Answer the following assertions by $\mathrm{A}=\mathrm{Agree}, \mathrm{D}=\mathrm{Disagree}, \mathrm{U}=\mathrm{Undecided}$.

i) Physical punishment is a good corrective measure......

ii) Physical punishment has negative impacts.....

iii) Physical punishment should be abolished (banned) in schools.......

iv) Physical punishment keeps discipline in school.......

v) A teacher who beats children must be dismissed from school........

2. State some harmful punishments to which you are subjected in your school

3. Was this punishment helpful (did it bring any positive change in your life)?

Tick one. Yes No

4. Caning may be bad and sometime good. What do you think?

5. If you think that physical punishment should be abolished in school suggest alternative to physical punishment

THANK YOU. 